\title{
KOMUNIKASI INKLUSI FRAMING SEBAGAI UPAYA PENANGANAN ANAK KORBAN KEKERASAN SEKSUAL (STUDY KASUS KORBAN KEKERASAN SEKSUAL UPTDDINAS SOSIAL KAMPUNG ANAK NEGERI SURABAYA)
}

\author{
Amalia Alvi \\ Universitas Islam Negeri Sunan Ampel Surabaya \\ amalia@gmail.com
}

\begin{tabular}{l}
\hline \hline Article Info \\
\hline Article history: \\
Received 14 February 2018 \\
Accepted 16 March 2018 \\
Published 10 April 2018 \\
\hline
\end{tabular}

Keyword:

Komunikasi inklusi, reframing dan kekerasan seksual

\section{Abstract}

Penelitian ini membahas tentang: (1) Dampak kekerasan seksual yang dialami anak binaan UPTD Dinas Sosial Kampung Anak Negeri Surabaya. (2) Proses konseling dengan menggunakan teknik Reframing dalam komunikasi inklusi sebagai upaya penanganan anak korban kekerasan seksual di UPTD Dinas Sosial Kampung Anak Negeri Surabaya, (3) Bagaimana hasil akhirkonseling dengan menggunakan teknik Reframing dalam komunikasi inklusi sebagai upaya penanganan anak korban kekerasan seksual di UPTD Dinas Sosial Kampung Anak Negeri Surabaya.

Metode yang digunakan adalah metode deskriptif komparatif. Hasil penelitian menujukkan klien mengalami trauma dan ketakutan yang mendalam sehingga memengaruhinya dalam beradaptasi dan berkomunikasi dengan teman-teman dan lingkungannya. Dalam proses konseling dengan menggunakan teknik refreming konselor memberikan gambaran serta sudut pandang baru untuk memperluas cakrawala berpikirdan berpandangan bagi klien sehingga klien bisa mengatasi ketakutannya. Hasil akhir dari proses konseling dengan menggunakan teknik Reframing dalam penelitian ini dikatakan tidak berhasil dengan persentase 30\%. yang mana hasil tersebut dapat dilihat dari adanya perubahan kecil padabeberapa sikap dan pengontrolan emosional negatif dan interaksi denganlingkungan sekitar. 


\section{Pendahuluan}

Kasus kekerasan seksual terhadap anak di bawah umur di Indonesia akhirakhir ini sangat marak didengar dari berbagai media, baik media cetak, maupun media elektronik seperti televisi, dan internet. Bahkan, beberapa kasus kekerasan seksual tersebut disertai dengan tindak pembunuhan terhadap koraban. Direktur Jenderal (Dirjen) Hak asasi Manusia (HAM) Mualimin Abdi dalam membacakan sambutan Menteri Hukum dan Hak Asasi Manusia (Menkumham) berkata bahwa kasus kekerasan seksual terhadap anak di indonesia dikategorikan dalam kondisi 'darurat', dan masuk kategori kekerasan luar biasa, karena mengancam dan membahayakan jiwa anak, serta masa depan bangsa. Menurut data yang dikumpulkan oleh Pusat Data dan Informasi Komisi Nasional Perlindungan Anak Indonesia dari tahun 2010 hingga tahun 2014 tercatat sebanyak 21.869.797 kasus pelanggaran hak anak, yang tersebar di 34 provinsi, dan 179 kabupatan dan kota. Sebesar $42-58 \%$ dari pelanggaran hak anak itu, merupakan kekerasan seksual terhadap anak. Data dan korban kekerasan seksual terhadap anak setiap tahun terjadi peningkatan. Pada 2010, ada 2.046 kasus, diantaranya $42 \%$ kekerasan seksual. Pada 2011 terjadi 2.426 kasus (58\% kekerasan seksual), dan 2012 ada 2.637 kasus (62\% kekerasan seksual). Pada 2013, terjadi peningkatan yang cukup besar yaitu 3.339 kasus, dengan kekerasan seksual sebesar 62\%. Sedangkan pada
2014 (Januari-April), terjadi sebanyak 600 kasus atau 876 korban.

Komisi Perlindungan Anak Indonesia juga menemukan banyak aduan kekerasan pada anak pada tahun 2010. Dari 171 kasus pengaduan yang masuk, sebanyak 67,8 persen terkait dengan kasus kekerasan. Dan dari kasus kekerasan tersebut yang paling banyak terjadi adalah kasus kekerasan seksual yaitu sebesar 45,7 persen (53 kasus). Komisi Nasional Perlindungan Anak (Komnas Anak) mencatat, jenis kekerasan anak tertinggi sejak tahun 2007 adalah tindak sodomi terhadap anak. Tahun 2007, jumlah kasus sodomi anak, tertinggi di antara jumlah kasus kekerasan anak lainnya. Dari 1.992 kasus kekerasan anak yang masuk ke Komnas Anak tahun itu, sebanyak 1.160 kasus atau 61,8 persen, adalah kasus sodomi anak. Dari tahun 2007 sampai akhir Maret 2008, jumlah kasus sodomi anak sendiri sudah naik sebesar 50 persen. Pada tahun 2009 lalu ada 1998 kekerasan meningkat pada tahun 2010 menjadi 2335 kekerasan dan sampai pada bulan maret 2011 paling tidak dari pantauan Komisi Nasional Perlindungan Anak ada 156 kekerasan seksual khususnya sodomi pada anak. ${ }^{1}$

Kekerasan terhadap anak tidak hanya meninggalkan luka secara fisik, lebih dari itu, kekerasan ini akan memberikan efek buruk pada perkembangan emosional, sosial, dan psikologi korban kekerasan. Bahkan, tidak jarang korban mengalami gangguan psikologis di masa yang akan

\footnotetext{
${ }^{1}$ Robertus Bilaminus, "LPSK: Kasus Kekerasan Seksual terhadap anak", Kompas (online), Diakses tanggal 22 Juni 2016.
} 
datang. Lebih dari itu, apabila korban tidak mendapatkan penanganan dengan baik, kemungkinan besar anak akan tumbuh menjadi pribadi yang sarat berbagai gangguan emosional seperti depresi hingga hangguan mental serius. Status "darurat perlindungan anak" yang disandang sejak tahun 2014 ternyata tidak membuat situasii perlindungan anak di 2015 dan 2016 menjadi lebih baik. $^{2}$

Efek kekerasan seksual terhadap anak antara lain depresi, gangguan stres pascatrauma, kegelisahan, kecenderungan untuk menjadi korban lebih lanjut pada masa dewasa, dan dan cedera fisik untuk anak di antara masalah lainnya. Pelecehan seksual oleh anggota keluarga adalah bentuk inses, dan dapat menghasilkan dampak yang lebih serius dan trauma psikologis jangka panjang dan munculnya perilaku menyimpang pada diri korban. ${ }^{3}$

Kekerasan seksual yang menyerang tidak memandang siapa dan seperti apa diri korban tersebut, namun dampak psikologisnya selalu mengiringi hingga korban dewasa nanti. ${ }^{4}$ Terdapat beberapa kasus mengenai korban kekerasan seksual yang memiliki beberapa keterbatasan, salah satunya adalah fisik. Ketidaksempurnaan fisik tidak menghalangi pelaku untuk berbuat tidak senonoh terhadap korban, bahkan keterbatasan itulah yang justru dimanfaatkan oleh pelaku sebagai upaya pencabulan terhadap korban. Karena pelaku merasa korban tidak mampu untuk melawan dan bereaksi terhadap perbuatan

${ }^{2}$ Mei Leandha, "Kasus kekerasan seksual pada anak Indonesia”, Kompas (online), Diakses tanggal 22 Oktober 2016. cabulnya. Keterbatan fisik yang dimaksud ialah masalah pada fungsi tubuh atau strukturnya, suatu pembatasan kegiatan adalah kesulitan yang dihadapi oleh individu dalam melaksanakan tugas atau tindakan, sedangkan pembatasan partisipasi merupakan masalah yang dialami oleh individu dalam keterlibatan dalam situasi kehidupan.

Kasus tersebut juga menimpa salah satu dari anak didik di UPTD binaan Dinas Sosial kota Surabaya, Anak tersebut mengalami kekerasan seksual lebih dari 1,5 tahun yang dilakukan oleh orang-orang terdekatnya, baik oleh lingkungan masyarakatnya maupun oleh lingkungan keluarganya. Selama mengalami perlakuan tersebut, korban mengalami tekanan batin karena belum memahami makna kejadian yang sebenarnya. Korban merupakan anak dengan keterbatasan pendengaran dan bicara yang dengan itu menyebabkan korban sulit untuk mengungkapkan perasaannya pada saat itu.

Latar belakang kehidupan korban juga tidak mendukung untuk melakukan perlindungan yang maksimal terhadapnya ditambah lagi lingkungan yang padat penduduk dan mayoritas merupakan masyarakat yang berpendidikan rendah bahkan mengabaikannya. Masyarakat di sekitar tempat tinggal korbanpun banyak yang telah mengetahui kejadian tersebut namun tak ada satupun yang mau menindak lanjutinya. Korban merupakan anak pertama dari empat bersaudara, Hobinya yang senang bermain ketika

3 Adi Suharto, "Kekerasan Terhadap Anak", (Bandung: Nuansa Cendekia) hal. 35

${ }^{4}$ Yanzi, Mark. Kekerasan Seksual dan Pemulihan. Jakarta: PT BPK Gunung Mulia. 2009 
malam hari mengantarkan dia pada kekerasan seksual yang selama ini dialaminya. Kejadian yang berturut-turut dan berselang lama ini menyisahkan dampak negatif yang kini menguasai emosionalnya dan hal itu menyebabkan korban dijauhi oleh orang-orang sekitarnya. Keterbatasan fisik korban juga menjadi salah satu penyebab susahnya berkomunikasi dengan orang lain, akibatnya banyak pihak yang semakin acuh.

\section{Kajian Pustaka}

\section{Teknik Reframing}

Reframing adalah teknik yang bertujuan untuk mereorganisir content emosi yang dipikirkannya dan membingkai kembali ke arah pikiran yang rasional, sehingga dapat mengerti berbagai sudut pandang dalam konsep diri/konsep kognitif dalam berbagai situasi. ${ }^{5}$

Pandangan tentang manusia menurut teknik ini bahwa manusia di dominasi oleh prinsip-prinsip yang menyatakan bahwa emosi dan pemikiran berinteraksi di dalam jiwa. Manusia memiliki kecendrungan yang inheren untuk menjadi rasional dan irasional dan bahwa gangguan perilaku dapat terjadi karena kesalahan dalam berpikir.

Reframing merupakan membingkai ulang suatu kejadian dengan merubah sudut pandang, tanpa mengubah kejadiannya itu sendiri. Framing digunakan sebagai alat untuk membingkai kembali masa lalu yang dianggap sebagai

5 Stephen Palmer, Konseling dan Psikoterapi, (Yogyakarta: Pustaka Pelajar, 2010) hal. 99

${ }^{6}$ Siti Fatimah, pengembangan paket keterampilan komunikasi konseling melalui teknik reframing bagi penyebab dari keadaan mentalnya saat ini. Reframing sering digunakan sebagai teknik mempengaruhi dalam membantu menolong meyakinkan seseorang untuk melihat beberapa gambaran atau ide dari pandangan yang berbeda.

Framing mempunyai banyak tujuan yang dengannya dapat mengubah seseorang menjadi lebih baik. Menurut Cormier, fokus dari strategi reframing terletak pada alasan yang salah dan keyakinan serta kesimpulan yang tidak logis. Tujuannya adalah mengubah keyakinan irrasional atau pernyataan diri negatif. $^{6}$

\section{Komunikasi Inklusi}

Komunikasi sebagai ilmu yang multidisiplin mempunyai banyak pengertian dan makna sesuai dengan latar belakang bidang ilmu yang memberi pengertian. Frank Dance mencoba memberikan tiga konseptual yang membentuk dimensi dasar definisi komunikasi, yaitu tingkat pengamatan, tujuan, dan penilaian normatif. Dimensi pengamatan atau keringkasan yakni definisi komunikasi yang diberikan berdasarkan kategori pengertian yang masih umum, luas dan bebas.

Misalnya, definisi komunikasi sebagai "proses yang menghubungkan semua bagian-bagian yang terputus" merupakan definisi komunikasi yang menggambarkan proses pengiriman dan penerimaan pesan dengan maksud tertentu. Misalnya, definisi komunikasi yang

mahasiswa BKI fakultas dakwah dan komunikasi uin sunan ampel surabaya, (Surabaya: Skripsi, 2016) hal 49 
menerangkan tentang "situasi-situasi tersebut merupakan sebuah sumber yang mengirimkan sebuah pesan kepada penerima dengan tujuan tertentu untuk mempengaruhi perilaku penerima”.

Dimensi penilaian normatif yaitu definisi komunikasi yang menyertakan pernyataan tentang keberhasilan, keefektifan, atau ketepatan. Misalnya, komunikasi didefinisikan "komunikasi merupakan pertukaran sebuah pemikiran atau gagasan. Asumsinya adalah sebuah pemikiran atau gagasan berhasil ditukarkan. ${ }^{7}$ Secara sederhana kamus besar bahasa indonesia menyebutkan pengertian "komunikasi" sama dengan perhubungan. Dengan komunikasi orang dapat menyampaikan pesan-pesan tertentu kepada kelompok ataupun kepada masyarakat luas

Onong Uchyana Effendy dalam bukunya. Ilmu Komunikasi: Teori Dan Praktek Mengatakan: komunikais pada hakekatnya adalah proses penyampaian pikiran atau perasaan oleh komunikator kepada komunikan. ${ }^{8}$ Carl I. Hovland dalam buku Social Communication menjelaskan: komunikasi adalah proses bilamana seseorang individu (Komunikator) mengoper stimulan (biasanya lambang kata-kata) untuk merubah tingkah laku individu lainnya (Komunikan) (Communication is the process by which an individual) (The Communicator) transmits stimuli [usually verbal symbol] to modify

\footnotetext{
7 Ali Nurdin, Pengantar Ilmu Komunikasi, (Surabaya: IAIN Press, 2013) hal. 6-7

${ }^{8}$ Ali Nurdin, Pengantar Ilmu Komunikasi, hal. 9

9 H.A.W Widjaja, Ilmu Komunikasi; Pengantar Studi, (Jakarta: PT Rineka Cipta, 2000) hal 15
}

the behaviour of other indivisuals communicant). ${ }^{9}$

Sedangkan klasifikasi inklusi adalah; Pertama, Anak Tunagrahita. Anak tunagrahita secara umum mempunyai tingkat kemampuan intelektual dibawah rata-rata. Dalah bahasa indonesia istilah yang digunakan mislanya, lemah otak, lemah pikiran, lemah ingatan dan tunagrahita Tunagrahita adalah istilah untuk menyebut anak yang mempunyai kemampuan intelektual dibawah rata-rata, secara harfiah, tuna berarti merugi dan grahita adalah pikiran, dan dalam istilah asing disebut mental retardation, mentallity retarded, mental deficiency atau mental defective. Kauffman dan Hallahan menyebutkan bahwa keterbelakangan mental menunjukkan fungsi intelektual di bawah rata-rata yang disertai ketidakmampuan dalam penyesuaian perilaku dan terjadi padamasa pengembangan. Menurut AAMD menjelaskan bahwa retardasi mental adalah kondisi intelektual di bawah ratarata dengan IQ di bawah 84 yang muncul sebelum usia 16 tahun dan menunjukkan adanya hambatan dalam perilaku adaptif. ${ }^{10}$

Kedua, Anak dengan kesulitan belajar. Anak yang berprestasi rendah umumnya ditemui di sekolah, karena mereka pada umumnya tidak mampu menguasai bidang studi tertentu yang diprogram oleh guru berdasarkan kurikulum yang berlaku. Ada sebagian besar yang memiliki nilai sangat rendah,

\footnotetext{
${ }^{10}$ Antonius Aris Sudana, Konsep Dasar Pendidikan Anak Berkebutuhan Khusus, (Yogyakarta: Familia Pustaka Keluarga, 2013) hal. 11
} 
ditandai dengan tes IQ berada di bawah rata-rata normal. Untuk golongan ini disebut Slowlearners. ${ }^{11}$

Ketiga, Anak hiperaktif. Hiperaktif merupakan gangguan perilaku yang dialami oleh anak yang disebabkan oleh adanya gangguan dalam pengaruh pemusatan perhatian dan kadang-kadang diserti dengan hiperaktivitas. ${ }^{12}$

Ciri yang akan sangat mudah dikenali adalah anak akan selalu bergerak dari suatu tempat ke tempat lain, selain itu yang bersangkutan sangat jarang untuk berdiam diri selama kurang lebih 15 hingga 10 menit guna melakukan suatu tugas kegiatan yang diberikan oleh gurunya. ${ }^{13}$

Keempat, Anak Tunalaras. Dalam peraturan pemerintah No. 72 tahun 1991 menyebutkan bahwa tuna laras adalah gangguan atau hambatan atau kelainan tingkah laku sehingga kurang dapat menyesuaikan diri dengan baik terhadap lingkungan keluarga, sekolah dan masyarakat. ${ }^{14}$

Kauffman menyatakan bahwa anakanak yang mengalami gangguan perilaku adalah anak yang secara nyata dan menahun merespon lingkungan tanpa adanya kepuasan berarti, namun bukan berarti mereka tidak dapat diajarkan perilaku yang sesuai norma. Anak tuna laras masih dapat diajarkan perilaku yang

\footnotetext{
11 Bandi Dolphic, Pembelajaran anak berkebutuhan khusus, (Bandung: PT Refika Aditama, 2006) hal. 24-25.

12 Rini Hildayani, Penanganan anak berkelainan (anak dengan kebutuhn khusus), (Jakarta: Universitas Terbuka), hal. 10.3

${ }^{13}$ Bandi Dolphic, Pembelajaran anak berkebutuhan khusus, (Bandung: PT Refika Aditama, 2006) hal. 74.
}

dapat diterima oleh masyarakat dan memuaskan pribadinya. ${ }^{15}$

Kelima, Anak Tunarungu.

Tunarungu dapat diartikan sebagai suatu keadaan kehilangan pendengaran yang mengakibatkan seseorang tidak dapat menangkap berbagai rangsangan terutama melalui indra pendengaran. ${ }^{1616}$ Batasan pengertian anak tunarungu telah banyak dikemukakan oleh para ahli yang semuanya itu pada dasarnya mengandung pengertian yang sama.

Heward dan Orlansky memberikan batasan ketunarunguan sebagai berikut: Tuli (Deaf) diartikan sebagai kerusakan yang menghambat seseorang untuk menerima rangsangan semua jenis bunyi dan sebagai suatu kondisi dimana suarasuara yang dapat dipahami, termasuk suara pembicaraan tidak mempunyai arti dan maksud-maksud dalam kehidupan seharihari.

\section{Anak korban kekerasan seksual}

Kekerasan seksual menurut YKAI (Yayasan Kesejahteraan Anak Indonesia) menyebutkan bahwa kekerasan seksual merupakan suatu perbuatan yang dapat menyebabkan anak kehilangan hal-hal yang paling mendalam dalam kehidupannya dan pada gilirnnya berdampak sangat sakit pada kehidupan anak di kemudian hari. ${ }^{17}$

14 IG.A.K. Wardani, Pengantar pendidikan luar biasa, (Jakarta: Universitas Terbuka,2010) hal 27.

${ }^{15}$ Antonius Aris Sudana, Konsep Dasar Pendidikan Anak Berkebutuhan Khusus, (Yogyakarta: Familia Pustaka Keluarga, 2013) hal. 17

${ }^{16}$ Sutjihati soemantri, Psikologi Anak Luar Biasa, (Bandung: PT refika Aditama, 2007, cet II) hal 84. 17 Adi Suharto, Kekerasan Terhadap Anak, (Bandung: Nuansa Cendekia, 2012) hal. 58 
Kekerasan seksual anak dapat diartikan sebagai suatu bentu penyiksaan anak dimana orang dewasa atau remaja yang lebih tua menggunakan anak untuk rangsangan seksual. Bentuk pelecehan seksualnya adalah termasuk meminta atau menekan seorang anak untuk melakukan aktivitas seksual, memberikan paparan yang tidak senonoh terhadap alat kelamin untuk anak, menampilkan poornografi kepada anak, melakukan hubungan seksual terhadap anak, kontak fisik terhadap alat kelamin anak (kecuali dalam konteks tertentu seperti, pemeriksaan medis) atau menggunakan anak untuk memproduksi pornografi anak. ${ }^{18}$

Kekerasan terhadap anak-anak yang terjadi di sekitar kita dan bahkan oleh lingkungan keluarga anak yakni orang tua. Kasus-kasus kejahatan pada anak tidak hanya terjadi di perkotaan tapi juga di pedesaan. Sementara itu sebagian besar para pelaku kekerasan seksual anak adalah orang yang dikenal oleh korban, sekitar $30 \%$ adalah keluarga dari si anak, paling sering adalah saudara laki-laki, ayah, paman atau sepupu, sekitar $60 \%$ adalah kenalan lainnya seperti teman dari keluarga, pengasuh, atau tetangga, dan sekitar $10 \%$ adalah orang asing dalam kasus kekerasan seksual pada anak. ${ }^{19}$

Didalam, kehidupannya manusia memiliki berbagai macam kebutuhanyang

\footnotetext{
18 Sri Andayani, "Bimbingan Konseling Islam melalui model pendidikan seks bagi siswa SD untuk mengurangi kekerasans seksual pada anak di desa condong kecamatan gading kabupaten Probolinggo" (Skripsi, Fakultas Dakwah Dan Komunikasi UIN Sunan Ampel Surabaya, 2016) hal 36-37.

${ }^{19}$ (http://id.m.wikipedia.org/wiki/pelecehan_seksua 1 terhadap_anak) (diakses, 09 Desember 2016
}

harus dipenuhi termasuk kebutuhan seksual. Dorongan seks ini sangat kuat dan dorongan ini menuntut untuk selalu dipenuhi. Apabila tidak dapat dikendalikan, maka akibatnya kebutuhan akans seks ini tidak tersalurkan secara normal, maka dapat terjadi penyimpanganpenyimpangan seperti halnya perkosaan.

Media massa merupakan sarana informasi dalam kehidupan sosial, misalnya seperti surat kabar, majalah, televisi dan sebagainya yang merupakan alat kontrol yang memegang peranan penting di dalam kehidupan bermasyarakat. Alat media massa yang paling besar pengaruhnya terhadap timbulnya kejahatan kesusilaan atau perkosaan adalah pemutaran film-film porno, kaset video porno, dan beredarnya gambar-gambar serta bacaan porno yang menimbulkan hasrat seksual bagi yang melihat dan mendengarnya. ${ }^{20}$

Dampak menonton film yang bersifat pornografi di VCD terhadap perilaku remaja adalah terjadinya peniruan yang memprihatinkan. Peristiwa dalam film memotivasi dan merangsang kaum remaja untuk meniru atau memprihatinkan hal yang dilihatnya.

Akibatnya remaja yang semakin permisif terhadap perilaku dan norma yang ada. Roviqoh melaporkan bahwa koresponden yang terangsang setelah

20 Sri Andayani, "Bimbingan Konseling Islam Melalui Model Pendidikan Seks Bagi Siswa SD Untuk Mengurangi Kekerasans Seksual Pada Anak Di Desa Condong Kecamatan Gading Kabupaten Probolinggo" (Skripsi, Fakultas Dakwah Dan Komunikasi UIN Sunan Ampel Surabaya, 2016) hal $41-42$ 
menonton tayangan porno sebanyak $84,4 \%$ dan sebanyak 2,2\% berakhir dengan melakukan hubungan seksual dan 31,5\% melakukan onani/masturbasi. Dari 92 koresponden yang terangsang oleh pornografi sebanyak 90,2\% terangsang kerena adegan seks dalam film. Pornografi menyebabkan dorongan seksual tinggi pada responden remaja laki-laki sebesar $50,9 \%$ dan pada perempuan sebesar $5,1 \% .^{21}$

\section{Metode Penelitian}

Pada penelitian ini penulis menggunakan pendekatan Kualitatif. Yang mana pendekatan kualitatif merupakan suatu proses unruk menemukan pengetahuan dengan lebih mengedepankan orang atau manusia sebagai objeknya, disini peneliti merupakan pihak kunci. Untuk memperoleh pemahaman yang lebih luas dan mendalam terhadap keadaan yang diteliti sehingga data yang diperoleh lebih akurat dan mendalam.

Adapun jenis penelitiannya, penulis akan menggunakan jenis penelitian Study Kasus, penelitian study kasus merupakan penelitian dengan pengujian secara rinci terhadap satu latar belakang atau satu orang subjek atau satu tempat penyimpanan dokumen atau satu peristiwa tertentu. Pendekatan study kasus sebagai suatu pendekatan dengan memusatkan perhatian pada suatu kasus secara intensif dan rinci

${ }^{21}$ Euis Supriati, "efek paparan pornografi pada remaja SMP Negeri Kota Pontianak Tahun 2008", Jurnal Sosial Humaniora, (online), Vol 13 No.1.

\section{Hasil dan Pembahasan}

Proses Pelaksanaan Teknik Reframing dalam Komunikasi Inklusi Sebagai Upaya Penanganan Anak Korban Kekerasan Seksual

Masalah merupakan satu beban yang sangat menganggu bagi siapa saja yang memilikinya, namun pada hakikatnya tidak ada satu orangpun yang tidak memiliki masalah, baik itu masalah yang timbul dari dirinya sendiri yang ditujukan dengaPron lingkungannya atau sebaliknya maupun masalah yang timbul dari lingkungan. Masalah yang timbul dari anggota keluarga merupakan masalah yang sering terjadi di lapangan, komunikasi yang tidak efektif antara satu anggota keluarga dengan anggota keluarga yang lain bisa jadi pemicu munculnya konflik sehingga bisa merugikan orang-orang dalam keluarga tersebut.

Dalam proses pelaksanaan ini, konselor berusaha menciptakan rapport (hubungan konseling yang bersahabat hingga terjalin keakraban) dan konselor menciptakan keakraban dengan klien dengan sering mengajaknya untuk berdiskusi santai meskipun klien masih lebih banyak diam dan hanya memberikan respon minimal.

Untuk mendeskripsikan masalah yang di alami oleh klien, maka konselor mencari informasi dengan melakukan wawancara dan observasi dengan beberapa pihak terkait yang hadir dalam kehidupan sehari-hari klien. Pertama kali konselor melakukan wawancara dengan klien

Juli 2009, (http://www.ejournal.gunadarma.ac.id, diakses 09 Desember 2016, 11.36). 
langsung, klien yang awalnya datang kepada konselor untuk menceritakan keluhannya, namun klien hanya mengatakan ini cerita tanpa banyak berkomentar yang lain. Konselor juga tidak memaksa klien untuk bercerita panjang saat itu.

Sedangkan Langkah-langkah yang diambil adalah sebagai berikut;

Pertama, Identifikasi Masalah. Langkah ini dimaksudkan untuk mengenal gejala-gejala yang tampak. Dalam langkah ini, konselor mencatat konseli yang mendapat bimbingan dan memilih klien yang perlu mendapat bimbingan lebih dahulu. $^{22}$ Apabila hubungan konseling telah terjalin baik, maka konselor memulai mencari sasaran-sasaran spesifik dan tingkah laku seperti apa yang menjadi ukuran keberhasilan konseling. Konselor perlu memperjelas tujuan yang ingin dicapai oleh mereka berdua. Hal penting dalam langkah ini adalah bagaimana keterampilan konselor dapat mengangkat isu dan masalah yang dihadapi klien.

Kemudian diidentifikasi dan didiagnosis secara cermat. Sering kali klien tidak begitu jelas mengungkapkan masalahnya, atau ia hanya secara samar menjelaskannya. Apabila hal ini terjadi, konselor harus membantu klien mendefiniskan masalah-masalahnya secara tepat agar tidak terjadi kekeliruan dalam diagnosis. Hal penting lainnya dalam langkah ini adalah membicarakan struktur konseling. Ini dilakukan untuk menunjukkan konselor dalam proses

\footnotetext{
22 Anas Salahuddin, Bimbingan dan Konseling
} (Bandung: Pustaka Setia, 2010), hal. 95 konseling agar tidak kehilngan arah yang ingin dicapai. ${ }^{23}$

Setelah melalui proses pengamatan dan wawancara terhadap pembina bisa diketahui bahwa Zainul merupakan anak yang berkebutuhan khusus yakni bisu dan tuli dan merupakan anak yang kebetulan bertempat di UPTD kampung anak negeri dengan kategori penempatan sebagai anak terlantar. Karena penelantaran itulah Zainul menjadi korban kekerasan seksual oleh orang-orang di sekitar tempat tinggalnya tersebut. Selama beberapa tahun Zainul mengalami kekerasan seksual dan pada saat itulah Zainul diposisikan layaknya seorang lawan dalam seksualitas oleh pelaku sehingga membekas dalam pikirannya tentang interpretasi lingkungan serta orang-orang terdekat yang telah melakukan perbuatan tersebut kepadanya.

Pikiran negatif mulai bermunculan dan berkembang Seiring berjalannya waktu Zainul menganggap tidak ada orang yang tulus menyayanginya seperti ibunya, termasuk teman-teman dan pembinanya. Hal itu dapat diketahui melalui hasil wawancara dengan salah satu pembina terkait permasalahan klien, pembina mengatakan "Zainul seringkali menjawab tidak suka dengan teman-temannya mbak, dia selalu menjauh dan mengatakan kalau sering dipukul dan dibentak oleh temantemannya" makanya Zainul lebih memiilih menarik diri dari teman-temannya tersebut.

Semenjak kejadian tersebut Zainul bukan hanya dijauhi oleh orang-orang dan dikucilkan, tetapi juga dibully karena

\footnotetext{
23 Namora Lumongga Lubis, Memahami Dasardasar Konseling dalam Teori dan Prkatek (Jakarta: Prenada Media Group, 2011), hal. 84
} 
seringnya menarik diri dari temantemannya dan membuatnya semakin dikenal berkepribadian aneh oleh temantemannya. Banyak dari teman-temannya yang mengatakan kepada konselor "si bisu itu aneh mbak, gak suka kumpul dengan kawannya dan sukanya mojok, paling yah lagi bayangin begituan mbak" teman satunya pun menimpali "mbak gak usah deket-deket sama dia, dia ituloh gak suka sama perempuan, dia pacarnya laki-laki semuanya mbak". hal ini membuat Zainul semakin menguatnya perasaan benci dan tidak suka terhadap orang lain. Zainul yang kini bertempat tinggal di UPTD Dinas Sosial Kampung Anak Negeri merasa sulit dalam beradaptasi, seringkali Ia mengalami tindak kekerasan baik disengaja maupun tidak disengaja. Hal ini menjadikannya lebih tidak bisa membuka diri dalam berteman dengan orang lain, dalam benaknya tidak ada seorangpun yang bisa dipercaya semenjak Ia ditinggal pergi oleh Ayahnya dan tinggal bersama dengan Ibunya. Selain kurang mampunya beradaptasi Zainul juga mempunyai permasalahan sulitnya mengontrrol emosi negatif yang ada pada dirinya, hal ini membuat teman-temannya enggan untuk mendekatinya, dikarenakan keterbatasan itu teman-temannya menjadi lebih bersemangat untuk membullynya dan melakukan kekerasan fisik terhadapnya.

Satu-satunya orang yang dipercaya Zainul adalah ibunya, namun permasalahannya sekarang adalah ketika Ia berada jauh dari Ibunya dan mempunyai dunia yang berbeda dengan ibunya, Ia pasti dituntut untuk bisa berkomunikasi dan berinteraksi dengan yang lainnya, namun pada kenyataannya Ia malah tidak bisa membuka diri bagi orang lain di tempat Ia tinggal dan berteduh. Selain dar itu, permasalahan yang telah dialaminya yakni susahnya pengontrolan dalam hal emosional, sehingga menyebabkan ketidakstabilan emosi yang mempengaruhi sikap serta tingkah lakunya. Hal ini merupakan faktor penting penyebab Ia menjadi seorang yang tertutup.

Kedua, Diagnosis. Setelah melakukan wawancara dengan klien, Konselor menyimpulkan masalah yang tengah dihadapi oleh klien. Setelah melakukan identifikasi masalah, maka langkah selanjutnya dalah mendiagnosa masalah klien, tahap diagnosa yaitu tahap untuk menetapkan masalah yang dihadapai klien beserta latar belakangnya. Dalam hal ini, kegiatan yang dilakukan ialah mengumpulkan data dengan mengadakan studi terhadap klien, menggunakan berbagai studi terhadap klien, menggunakan berbagai teknik pengumpulan data. Setelah data terkumpul, ditetapkan masalah yang dihadapi serta latar belakangnya.

Ketiga, Prognosis. Setelah konselor melakukan diagnosis terhadap klien, maka tahap selanjutnya adalah prognisis, tahap ini adalah tahap untuk menetapkan jenis bantuan yang akan dilaksanakan untuk membimbing anak. Langkah prognosis ini ditetapkan berdasarkan kesimpulan dalam langkah diagnosis, yaitu setelah ditetapkan masalahnya dan latar belakangnya. Langkah prognosis ini, ditetapkan bersama setelah mempertimbangkan berbagai kemungkinan dan berbagai faktor. Membuat penaksiran dan penjajakan. 
Konselor berusaha menjajaki atau menaksir kemungkinan masalah dan merancang bantuan yang mungkin dilakukan. Caranya dengan mengubah persepsi negatif klien menjadi persepsi positif sekaligus memberikan gambaran baru pada klien diluar pemahamannya selama ini.

Setelah melihat permasalahan klien dan faktor-faktor yang mempengaruhi munculnya masalah pada klien, maka konselor akan melakukan teknik reframing dengan menggunakan komunikasi inklusi yang dilakukan secara langsung dan bertahap kepada klien. Hal ini dirasa ampuh untuk membantu klien karena masalah klien saat ini berkaitan erat dengan pengaruh masa lalu yang terbawa hingga saat ini.

Keempat, Treatmen atau terapi. Teknik yang sudah diterapkan oleh Konselor untuk menyelesaikan masalah klien diterapkan oleh Konselor dengan berdasarkan langkah-langkah teknik reframing yaitu;

1. Rasional, rasional digunakan dalam strategi reframing bertujuan untuk meyakinkan konseli bahwa persepsi atau retribusi masalah dapat menyebabkan tekanan emosi. Konselor memberikan penekanan terhadap kejadian yang dialami oleh Klien agar klien bisa menerima keadaan dirinya saat ini, dengan demikian Klien tidak akan dihantui oleh ketakutan terhadap kenyataan hidupnya.

2. Identifikasi persepsi. identifikasi persepsi merupakan suatu tahapan untuk mengidentifikasi persepsi atau pikiran-pikiran yang muncul dalam situasi yang menimbulkan kecemasan. Ketika proses konseling dilakukan, maka konselor akan menangkap peluang ketakutan yang sedang dialami oleh klien, mengingat hal ini merupakan hal yang wajar bagi seseorang yang telah lama memendam kecemasan dan mulai dimunculkan kembali dengan tujuan untuk memperkecil ketakutan tersebut.

3. Menguraikan peran dari fitur-fitur persepsi terpilih untuk dapat memerankan kondisi kecemasan yang telah diidentifikasi. Setelah rasa kecemasan yang telah lama tertekan ke dalam pikiran dimunculkan kembali, maka akan muncul reaksi ketakutan yang tak kaha hebat dengan kejadian seperti sebelumnya ketika mendapatkan trauma tersebut, namun konselor mecoba membawa klien untuk mengolah kecemasan tersebut dan melawannya.

4. Identifikasi persepsi alternatif yang digunakan ketika klien sudah mampu mengontrol perasaan dan pikiran negatifnya, maka langkah selanjutnya adalah konselor mengarahkan klien untuk menekan emosi negatifnya dan mengubahnya menjadi emosi positif sehingga klien akan mendapatkan perasaan positif dengan tanpa menghapusnya.

5. Modifikasi dan persepsi merupakan upaya berlatih dalam mengalihkan persepsi lama menjadi persepsi yang baru dengan mengubah kecemasan dan ketakutan menjadi suatu hal yang lebih positif. Konselor mengupayakan agar klien menemukan makna dari kejadian 
yang telah dialami tersebut sehingga klien mampu menginterpretasikannya dengan tindakan yang lebih positif.

6. Pekerjaan rumah dan tindak lanjut untuk berlatih dalam melakukan pengubahan secara cepat dari persepsi lama ke persepsi atau sudut pandang yang baru dan menerapkannya dalam kondisi yang nyata atau sebenarnya.

Teknik yang sudah diterapkan oleh Konselor untuk menyelesaikan masalah klien diterapkan oleh Konselor dengan cara memperbaiki sudut pandang Klien dengan mengembalikan gambaran kejadian disertai dengan rasionalisasi sehingga Konselor mengajak Klien untuk berpikir dan memperbaiki kehidupannya di masa mendatang dengan mengurangi beban emosional dan menerima keadaan dirinya. Konselor akan membangun kepercayaan dengan klien, dengan demikian Klien akan berusaha untuk mengikuti saran dan tindakan konselor selama dalam koridor untuk mencapai kebaikan Klien.

Dengan perubahan sudut pandang tersebut diharapkan Klien dapat memperoleh sudut pandang baru yang lebih meluas dan lebih baik dari sebelumnya, dengan demikian, Klien dapat mengontrol dan mengatur emosinya dengan baik serta dapat menerima keadaan di lingkungan sekitarnya, Klien pun dapat mendapatkan kepercayaan dirinya kembali dan dapat hidup dengan tanpa rasa ketakutan yang berlebihan.

Setelah melalui proses Treatmen dan terlihat perubahan yang signifikan terhadap klien sehingga Klien terlihat lebih baik, dari segi kepercayaan diri, pengaturan emosional hingga penerimaan dan keterbukaan lingkungannya, maka proses konseling yang selama ini dilakukan dirasa cukup dan konselorpun mulai mengakhiri proses Klienng, namun konselor tidak lupa meminta terhadap klien untuk tetap berkomunikasi dan mengonsultasikan permasalahannya jika suatu saat terjadi hal-hal yang tidak didinginkan, konselor dan Klien pun saling bertukar nomor handphone sehingga dapat memudahkan Komunikasi antar kedua belah pihak. Klien mulai menjalani kehidupannya dengan ceria, sekalipun rasa trauma dan ketakutan tidak hilang sama sekali namun, dengan perubahan sikap dan sifat yang dialami Klien, bisa dikatakan bahwa Klien sudah cukup bisa menekan emosinya dan bisa beradaptasi dengan lingkungannya.

\section{Pelaksanaan Komunikasi Inklusi Framing untuk Penanganan Anak Korban Kekerasan Seksual}

Klien yang semula mengalami ketakutan yang meyebabkannya menjadi tertutup, kurang kontrolnya emosi, sulitnya beradaptasi dan susah percaya terhadap orang lain. Setelah konselor memberikan bantuan dalam memecahkan permasalahan klien dengan menggunakan teknik Reframing.

Klien menyadari ketakutannya menjadi penyebab besar keadaannya saat ini, klien mulai membuka diri dan mulai bisa menerima keadaannya saat ini. Klien menyadari arti pentingnya teman dan saudara yang akan membantunya disaat susah, dan tidak menjadikannya objek bullyan sebagai kepuasan meraka dalam 
menyikapi perbedaan sikap dan sifat yang dimilikinya.

Klien menyadari masalahnya dan akan berjanji untuk mengubah mindsetnya dari negatif menjadi positif, ini terbukti setelah dilakukannya proses konseling terlihat beberapa perubahan yang ada pada diri klien, seperti tidak mudah marah ketika dijahili oleh temen-temannya, sudah mulai membuka diri dengan bermain bersama teman-temannya.

Klien juga sudah mulai bisa berkomunikasi dengan baik dengan orangorang di sekitar lingkungan tempat tinggalnya seperti, pembina, birokrasi kelembagaan, ibu kantin dan lain sebegainya. Klien kini seringkali melakukan shalat jamaah lima waktu dengan tepat waktu meskipun tanpa perintah atau arahan dari siapapun, meskipun beberapa kali juga diingatkan namun representasi teguran yang Ia dapatkan jauh berkurang ketimbang sebelumnya.

Saat ini klien sedang belajar untuk sepenuh hati beribadah dan bersosialisasi dengan lingkungan dan teman-temannya sekalipun hal tersebut susah menurut klien, Klien mempunyai keinginan untuk belajar berpuasa sunnah karena selama ini puasa wajib ramadhan yang dilakukannya kerap tak genap dengan berbagai macam alasannya. Klien juga memahami bagaimana harus bergaul dan berteman baik dengan teman-teman di lingkungannya dan klien juga berjanji untuk terus berteman dan berbuat baik kepada siapapun di lingkungan sekitarnya.

Berdasarkan pada masalah yang dihadapi oleh salah seorang anak binaan di
UPTD Dinas Sosial Kampung Anak Negeri Surabaya, Maka Konselor memilih menggunakan Teknik Reframing untuk melakukan proses terapi konseling. Terapi ini berpusat di Klien, bahwasanya klien diberikan kesempatan untuk mereorganisir content emosi yang dipikirkannya dan membingkai kembali ke arah pikiran yang rasional, sehingga dapat mengerti berbagai sudut pandang dalam konsep diri/konsep kognitif dalam berbagai situasi serta dapat mengubah sudut pandang negatif menjadi positif dengan membingkai ulang suatu kejadian dengan merubah sudut pandang, tanpa mengubah kejadiannya itu sendiri.

Teknik Reframing bersandar pada kesanggupan klien dalam mengubah sudut pandangnya mengenai masalalu yang berkaitan dengan kehidupannya saat ini, klien dapat memecahkan masalahnya sendiri dengan proses rasionalisasi dan penerimaan akan kejadian masa lalunya, Klien dapat mengatasi ketakutannya sendiri dan berusaha membuka diri pada kehidupannya saat ini.

Proses konseling pada pendekatan teknik ini memiliki 6 tahapan, yaitu; Rasional yang bertujuan untuk meyakinkan konseli bahwa persepsi atau retribusi masalah dapat menyebabkan tekanan emosi, Identifikasi persepsi bertujuan untuk mengidentifikasi persepsi atau pikiran-pikiran yang muncul dalam situasi yang menimbulkan kecemasan, Menguraikan peran dari fitur-fitur persepsi terpilih untuk dapat memerankan kondisi kecemasan yang telah diidentifikasi, Identifikasi persepsi alternatif yang bertujuan untuk memilih persepsi alternatif atau sudut pandang baru sebagai pengganti 
dari persepsi sebelumnya, Modifikasi dan persepsi bertujuan untuk mengalihkan persepsi lama (yang menimbulkan situasi tekanan dan kecemasan) ke persepsi baru, dan Pekerjaan rumah serta tindak lanjut untuk berlatih dalam melakukan pengubahan secara cepat dari persepsi lama ke persepsi atau sudut pandang yang baru dan menerapkannya dalam kondisi yang nyata atau sebenarnya

Dari hail proses bimbingan pribadi sosial yang sudah dilakukan disimpulkan bahwa proses bimbingan pribadi sosial dikatakan tidak berhasil, hal ini dilihat dari hasil presentase, diketahui bahwa hasil teknik reframing dalam komunikasi inklusi sebagai upaya penanganan anak korban kekerasan seksual di UPTD Dinas Sosial Kampung Anak Negeri dikategorikan Tidak berhasil. Keberhasilan ini dapat dilihat dari hasil perhitungan persentase bahwa dari 10 gejala, 3 gejala yang sudah tidak dilakukan atau 30\% melalui standar uji $>75 \%$ s/d $100 \%$ dikatakan berhasil. 5 gejala yang kadang-kadang masih dilakukan atau $50 \%$ melalui standar uji $50 \%$ s/d 75\% dikatakan kurang berhasil, dan 2 gejala yang masih dilakukan atau 20 $\%$ melalui standar uji $50 \%$ s/d $75 \%$ dikatakan tidak berhasil.

\section{Kesimpulan}

Proses bimbingan dan konseling islam dengan menggunakan teknik reframing dalam komunikasi inklusi sebagai upaya penanganan anak korban kekerasan seksual pada anak binaan UPTD kampung anak negeri surabaya korban kekerasan seksual yang sulit mengontrol emosi dan sulit berkomunikasi serta beradaptasi dengan teman-teman serta lingkungan sekitarnya. Proses bimbingan dilakukan dengan cara pertemuan langsung dengan memberikan gambaran baru mengenai kehidupan sehingga klien bisa mengubah persepsinya mengenai kehidupannya saat ini. Konselor memberikan gambaran tentang pentingnya bersosialisasi dalam hidup dan manfaat jika mampu berbaur dengan masyarakat, konselor menguatkan agar klien bisa mengalahkan rasa bencinya agar mampu membuka diri dan bersosialisasi dengan baik serta membuka diri bagi orang lain di sekitarnya. Konselor juga melatih klien agar mampu untuk meredam emosinya ketika bersama dengan teman-temannya, memulai untuk menyapa teman dan ikut serta dalam kegiatan sosial.

\section{Daftar Pustaka}

Bilaminus, Robertus. LPSK: Kasus Kekerasan Seksual terhadap anak. Kompas online. 22 Juni 2016.

Suharto, Adi. Kekerasan Terhadap Anak. Bandung: Nuansa Cendekia.

Rakhmat, Jalaluddin. Psikologi Komunikasi. Bandung: PT Remaja Rosdakarya, 2013.

Khris Hernadi, Arnas. "Sekolah Inklusi Untuk Anak Berkebutuhan Khusus (Abk)". Jurnal Pendidikan. Online. http://AK Hernadi - academia.edu.ac.id. diakses 10 Oktober 2016.

Oktaviana, Dian. "Penggunaan Strategi Reframing Untuk Membantu siswa Mengurangi Perasaan Cemas Ketika Bertanya di Kelas”. Jurnal Mahasiswa Teknologi. Online, http: 
//ejournal.unesa.ac.id, diakses 10 Oktober 2016.

Palmer, Stephen. Konseling dan Psikoterapi. Yogyakarta: Pustaka Belajar. 2011.

Prastya Yuliawan, Teddy. The Art Of Enjoying Life. Jakarta: Serambi Ilmu Semesta. 2014.

Santrock, Jhon W. Perkembangan Anak. Jakarta: Erlangga. 2007.

Nurdin, Ali. Pengantar Ilmu Komunikasi. Surabaya: IAIN Press. 2013.

Widjaja, H.A.W. Ilmu Komunikasi; Pengantar Studi. Jakarta: PT Rineka Cipta. 2000.

Mulyana, Deddy. Komunikasi; Suatu Pengantar. (Bandung: PT Remaja Rosdakarya.

Liliweri, Alo. Komunikasi; Serba Ada Serba Makna. Jakarta: Kencana. 2011.

Sudana, Antonius Aris. Konsep Dasar Pendidikan Anak Berkebutuhan Khusus. Yogyakarta: Familia Pustaka Keluarga. 2013.

Dolphic, Bandi. Pembelajaran anak berkebutuhan khusus. (Bandung: PT Refika Aditama. 2006.

Hildayani, Rini. Penanganan anak berkelainan anak dengan kebutuhn khusus Jakarta: Universitas Terbuka.

Wardani, IG.A.K. Pengantar pendidikan luar biasa. Jakarta: Universitas Terbuka.2010.

Soemantri, Sutjihati. Psikologi Anak Luar Biasa. Bandung: PT refika Aditama. 2007.

Fatimah, Siti. pengembangan paket keterampilan komunikasi konseling melalui teknik reframing bagi mahasiswa BKI fakultas dakwah dan komunikasi uin sunan ampel surabaya. Surabaya: Skripsi. 2016.

Devi Ana Ratih, Skripsi Penerapan Konseling Kelompok Menggunakan Strategi Reframing Untuk Meningkatkan Motivasi Belajar MatematikaPada Siswa Kelas VIII H SMP Negeri Pungging. Surabaya: Skripsi, 2015.

Andayani, Sri. "Bimbingan Konseling Islam melalui model pendidikan seks bagi siswa SD untuk mengurangi kekerasans seksual pada anak di desa condong kecamatan gading kabupaten Probolinggo". Skripsi. Fakultas Dakwah Dan Komunikasi UIN Sunan Ampel Surabaya. 2016.

http://id.m.wikipedia.org/wiki/peleceha n_seksual_terhadap_anak. Diakses. 09 Desember 2016. 10.54 .

Supriati, Euis. "efek paparan pornografi pada remaja SMP Negeri Kota Pontianak Tahun 2008". Jurnal Sosial Humaniora. (online). Vol 13 No.1. Juli 2009. http://www.ejournal.gunadarma.a c.id. diakses 09 Desember 2016, 11.36.

Fuadi, Anwar. "Dinamika Psikologis Kekerasan Seksual: sebuah studi Fenomenologi”. Journal Psikologi Islam. Online. Vol.08 No.02. Januari 2011. http://ejournal.uin-malang.ac.id. Di akses 09 Desember 2016, 11.47

Yanzi, Mark. Kekerasan Seksual dan Pemulihan. Jakarta: PT BPK Gunung Mulia. 2009.

Hasil wawancara dengan kak Hilda. salah satu pembina di UPTD Dinas Sosial Kampung Anak 
Negeri Surabaya. tanggal 01

Desember.

Hasil observasi dengan Pak Pupung.

Salah Satu Pembina di UPTD

Dinas Sosial Kampung Anak

Negeri Surabaya. pada tanggal 03

Desember 2016.

Leandha, Mei. Kasus kekerasan seksual pada anak Indonesia. Kompas online, 22 Oktober 2016. 